\title{
RITUAL BERANGKAT HAJI MASYARAKAT MUSLIM GORONTALO
}

\section{THE RITUAL OF DEPARTING HAJJ IN GORONTALO MUSLIM SOCIETY}

\author{
Muhammad Irfan Syuhudi \\ Peneliti Balai Penelitian dan Pengembangan Agama Makassar \\ J1. A.P. Pettarani No. 72 Makassar \\ Email: irfansyuhudi@gmail.com
}

Naskah diterima tanggal 22 Januari 2019, Naskah direvisi tanggal 4 Maret 2019, Naskah disetujui tanggal 30 Mei 2019

\begin{abstract}
Abstrak
Salah satu Rukun Islam adalah melaksanakan ibadah haji ke Baitullah, Mekkah. Meski begitu, ibadah haji merupakan kewajiban bagi orang-orang Islam yang dianggap mampu melaksanakannya. Dalam tradisi masyarakat Islam di Indonesia, sebagian besar masyarakat masih melaksanakan serangkaian ritual sebelum melaksanakan ibadah haji. Ritual haji tersebut bahkan dijadikan tradisi oleh calon jamaah haji beserta keluarga, seperti yang terlihat pada masyarakat Gorontalo berupa ritual "Baca Doa", yang di dalamnya mencakup Salawati (Selawat Nabi Muhammad SAW), Barzanji, Tadarusan (mengaji AlQuran), dan Zikir. Penelitian ini bertujuan untuk mendeskripsikan ritual "Baca Doa" calon jamaah haji sebelum berangkat ke Tanah Suci, dan gelar haji dikaitkan dengan konteks sosial pada masyarakat di Kota Gorontalo. Jenis penelitian ini adalah kualitatif, yang menyajikan data-data secara deskriptif, sedangkan penentuan informan dilakukan secara sengaja (purposive). Pengumpulan data melalui wawancara, observasi, dan penelusuran data sekunder terkait konteks tulisan. Hasil penelitian menunjukkan, ritual haji "Baca Doa" pada masyarakat Gorontalo terbagi ke dalam tiga tahap, yaitu sebelum berangkat haji, saat jamaah berada di Tanah Suci, dan penjemputan jamaah oleh keluarga. Ritual "Baca Doa" dimaksudkan untuk memperoleh kemudahan, keselamatan, kesehatan sejak calon jamaah haji meninggalkan rumah hingga pulang ke rumah, serta menjadi Haji Mabrur. Selain "Baca Doa", ada juga ritual yang dinamakan "pembersihan diri", yang dimaknai sebagai refleksi diri, bahwa orang yang merencanakan melaksanakan haji sebaiknya memperbanyak mendekatkan diri kepada Allah, karena mereka akan menuju ke tempat yang disucikan Allah. Gelar haji bagi orang Gorontalo dapat juga menaikkan status sosial mereka di lingkungan sosialnya. Seorang haji memperoleh keistimewaan saat menghadiri upacara sosial dan upacara siklus hidup.
\end{abstract}

Kata kunci: haji, ritual haji, baca doa, status sosial, Gorontalo

\begin{abstract}
One of the pillars of Islam is to perform the hajj to the House of Allah, Mecca. Even so, the hajj is an obligation for Muslims who are considered capable of carrying it out. In the tradition of Islamic society in Indonesia, most people still carry out a series of rituals before performing the hajj. The hajj ritual is even used as a tradition by prospective pilgrims and their families, as seen in the Gorontalo community in the form of the ritual of "Baca Doa", which includes Salawati (Salawat Prophet Muhammad SAW), Barazanji, Tadarrusan (recitation of the Quran), and Dhikr. This study aims to describe the ritual "Baca Doa" of pilgrims before leaving for the Holy Land, and the hajj title is associated with the social context of the people in Gorontalo City. This type of research is qualitative, which presents the data descriptively, while the determination of informants done intentionally (purposive). Data collection through interviews, observations, and secondary data related to the context of writing. The result of the research shows that the pilgrimage ritual of "Baca Doa" in Gorontalo society is divided into three stages, ie before the pilgrimage, when the pilgrims are in the Holy Land, and picking up the pilgrims by the family. The ritual of "Baca Doa" is intended to obtain the ease, safety, health since the pilgrims leave home and return home, and become Haji Mabrur. In addition to "Baca Doa", there is also a ritual called "self-cleansing", which is interpreted as self-reflection, that the person planning to perform the hajj should reproduce closer to God, because they will go to the place that is sanctified by God. The Hajj for the Gorontalo can also raise their social status in their social environment. A pilgrim earns privileges while attending social ceremonies and lifestyle ceremonies.
\end{abstract}

Keywords: hajj, hajj ritual, recite prayer, social status, Gorontalo 


\section{PENDAHULUAN}

I badah haji dipandang sebagai ritus kehidupan muslim di Indonesia, karena syahadat, salat, zakat, dan berpuasa (Ramadan). Berbagai hal dipertunjukkan secara simultan dalam menunaikan ibadah haji, seperti penciptaan, sejarah, keesaan, ideologi Islam, dan Ummah (Idris 2017, 240). Ritual keagamaan ditandai dengan "kehadiran" simbol-simbol kepercayaan yang melahirkan banyak interpretasi dari sistem kepercayaan tersebut. Beragam simbol itu merupakan akumulasi makna, sedangkan interpretasi terhadap simbolsimbol adalah interpretasi kebudayaan (Hamid 1982, 73). Hampir semua pelaksanaan ritual haji yang terjadi di dalam masyarakat dipenuhi dengan penafsiran atas simbol-simbol tersebut.

Ibadah haji erat pula kaitannya dengan dimensi sosial. Dalam banyak tradisi di Indonesia, gelar haji masih dipandang ikut mendongkrak status sosial seseorang dan keluarga. Mereka yang dulunya bukan siapasiapa, tetapi setelah menyandang gelar haji, kemudian dipandang orang istimewa. Gelar haji dan identitas baru yang melekat pada diri orang tersebut menjadikan mereka dipandang orang alim dan kaya. Maka dari itu, dalam kasus tertentu, ada juga orang yang berangkat haji ingin dipanggil "haji", dan tersinggung bila ada yang memanggil namanya tanpa menyertai embel-embel "haji". Pada orang semacam itu, mereka berhaji untuk menambah modal sosial (Maarif, 2017).

Anik Farida, yang meneliti pedagang Betawi menyebutkan, gelar haji bisa membuat yang bersangkutan "naik kelas". Malah, gelar haji disejajarkan dengan elite keagamaan, seperti halnya Kiai atau ulama, tanpa memandang kualitas keagamaan bersangkutan (Farida, 1999: 37-38). Ini juga menunjukkan, gelar haji dapat membuat seseorang dilabeli alim dan dianggap memahami agama tanpa melihat latar belakang tingkat pendidikan dan kualitas keagamaan mereka.

Pada masyarakat pedesaan Madura, gelar haji ikut berdampak terhadap kehidupan sosial mereka dan keluarga. Seorang haji akan mendapatkan perlakuan istimewa dari lingkungan sosialnya, khususnya pada upacaraupacara keagamaan dan siklus hidup (life cycle). Setiap kali mendapat undangan menghadiri upacara sosial dan upacara keagamaan, para haji diberikan tempat duduk terhormat, sejajar dengan para tokoh agama (Madani, 1984: 40). Betapa pentingnya pencapaian gelar haji, sehingga sebagian besar masyarakat di sana menganggap berangkat haji sebagai bagian dari cita-cita hidup yang harus mereka penuhi, tanpa memedulikan lagi apakah proses berangkat haji ini nantinya bakal menguras harta atau mempengaruhi kehidupan ekonomi mereka kelak (Madani, 1984: 30).

Gelar haji pada masyarakat Gorontalo juga menempati posisi terhormat di lingkungan sosialnya. Bagi masyarakat Gorontalo, gelar haji adalah gelar tertinggi umat Islam. Ia berbeda, dan tidak bisa disamakan dengan gelar formalistis yang diperoleh di bangku sekolah. Haji adalah panggilan Allah, dan orang-orang yang memenuhi panggilan Allah saja, yang akan berkunjung melaksanakan Rukun Islam kelima itu. Belum lagi, sebelum berangkat haji, orang Gorontalo melakukan serangkaian ritual yang menambah kesan "kesakralan" perjalanan haji. Di antaranya, ritual "pembersihan diri" dan ritual "Baca Doa".

Ritual "pembersihan diri" dilaksanakan oleh calon jamaah haji sebagai bentuk refleksi diri atas tindakannya selama ini. Dari refleksi diri tersebut, ia berharap terdapat perubahan perilaku sebelum haji dan setelah menyandang gelar haji. Sedangkan ritual "Baca Doa" yang di dalamnya berisi Salawati (baca Selawat kepada Nabi SAW) atau barzanji, tadarusan (mengaji), dan zikir, dilaksanakan sebelum calon jamaah haji berangkat, saat berada di Tanah Suci, dan menunggu kedatangan jamaah haji. Secara umum, "Baca Doa" dimaksudkan supaya jamaah haji diberi kemudahan, keselamatan, dan kesehatan dari Allah Swt. sejak meninggalkan rumah, hingga pulang ke rumah. Juga, supaya calon jamaah haji dapat melaksanakan semua Rukun Haji tanpa menemui kendala. 
Berdasarkan latar belakang di atas, penelitian ini mengajukan dua pertanyaan, yakni bagaimana ritual "Baca Doa" yang dilaksanakan calon jamaah haji sebelum berangkat ke Tanah Suci, dan bagaimana gelar haji dikaitkan dengan konteks sosial pada masyarakat di Kota Gorontalo. Penelitian ini bermaksud mendeskripsikan ritual "Baca Doa" dan ritual lainnya berkenaan pelaksanaan haji, serta mendeskripsikan pengaruh gelar haji di dalam kehidupan sosial budaya masyarakat Gorontalo.

\section{Tinjauan Pustaka Ritual}

Upacara keagamaan dan upacara sosial yang dilakukan oleh individu atau kelompok selalu disertai dengan ritual. Ritual dianggap bagian paling penting dalam agama, karena secara simbolik mengungkapkan hubungan penganutnya dengan Yang Gaib (Tuhan). Dalam Islam, ritual berarti ibadah, yang tata aturannya ditentukan dalam teks-teks suci. Berkaitan dengan ini, praktik-praktik ibadah ada yang ketentuan-ketentuannya sudah ditentukan dan pelanggaran terhadapnya dianggap penyimpangan, sehingga tidak boleh ditambahtambah. Sedangkan muslim lainnya, ada yang menempatkan praktik-praktik tambahan sepanjang ia mendapat legitimasi dari teks-teks suci (Al-Kumayi, 2011: 271).

Ritual juga merupakan upacara yang dikeramatkan oleh sekelompok umat beragama, yang ditandai dengan adanya waktu, tempat berlangsungnya upacara, alat-alat upacara, orang-orang yang menjalankan upacara, serta memakai pakaian tertentu (Koentjaraningrat, 1985: 56 dan Suprayogo, 2001: 41).

Pada umumnya, masyarakat Gorontalo mengenal tiga proses ritual haji, yaitu ritual sebelum berangkat haji, ritual saat jamaah di Tanah Suci, dan ritual menunggu kepulangan jamaah haji. Ritual tersebut dilaksanakan oleh calon jamaah haji, keluarga calon jamaah haji, dan para undangan. Ritual sebelum berangkat haji umumnya dilaksanakan di rumah, dan melibatkan imam dan ustaz untuk membaca Salawati (Selawat Nabi Muhammad SAW) atau barzanji. Ketika jamaah haji berada di Mekkah, dan menunggu kedatangan di tanah air, keluarga di rumah melakukan tadarusan (mengaji AlQuran) hingga khatam 30 Juz.

Secara etimologi, penyebutan ritual dan ritus adalah hal yang sama, yang bertujuan untuk mendapatkan berkah atau rezeki melimpah dari suatu pekerjaan yang tengah dijalani oleh individual atau kelompok/komunitas. Dalam hal ini, pada beberapa masyarakat, mereka kerap melaksanakan upacara siklus hidup (life cycle), atau ritual tertentu (ritual haji, misalnya), untuk melakoni sebuah babak baru di dalam kehidupan mereka (Bustanuddin, 2007: 95).

Antropolog Victor Turner, menyebutkan, ritual bertujuan untuk mendorong orang-orang melakukan dan menaati tatanan sosial tertentu, memberikan motivasi, serta nilainilai pada tingkat yang paling dalam. Ketika meneliti ritual masyarakat Ndembu Afrika Tengah, Turner mengemukakan, inti dari ritual yang dilaksanakan masyarakat merupakan penampakan terhadap keyakinan religius (Winangun 1990, 67). Ritual sering disimbolkan sebagai "kelahiran kembali" atau "kelahiran baru". Untuk mencapai status baru, seseorang mesti "mematikan status lamanya", dan kemudian menjadi marginal. Ritual juga menjadi sarana ekspresi perasaan dengan melakukan upacara yang dimaksudkan untuk mengembalikan jati diri dari suatu komunitas agama. Kesadaran muncul kembali melalui pelaksanaan ritual, sehingga suatu komunitas seakan kembali menjadi sesuatu yang suci (Idris, 2017: 240).

Fungsi dari serangkaian proses ritual juga adalah untuk menghilangkan kecemasan, seperti dikemukakan George Homans, bahwa pelaksanaan ritual sebenarnya berawal dari rasa kecemasan. Homans kemudian membagi kecemasan menjadi dua tingkatan, yaitu kecemasan yang bersifat "sangat" yang disebutnya kecemasan primer, dan kecemasan "biasa", yang disebutnya kecemasan sekunder. Kecemasan primer, melahirkan ritual primer, sedangkan kecemasan sekunder melahirkan ritual sekunder. Homans lalu mendefinisikan ritual primer sebagai upacara yang bertujuan untuk mengatasi kecemasan, tetapi tidak langsung berpengaruh terhadap tercapainya tujuan. Sedangkan, ritual sekunder dimaksudkan sebagai upacara penyucian untuk kompensasi 
kemungkinan kekeliruan atau kekurangan dalam ritual primer (Djamari, 1993: 38). Orang Gorontalo yang akan berangkat haji juga merasakan kecemasan sebelum berangkat haji. Karena itu, dengan beragam ritual yang dilakukan, mereka berharap perjalanannya menuju Baitullah berjalan lancar, kondisi mereka sehat, dan memperoleh Haji Mabrur.

\section{Gelar Haji dalam Konteks Sosial}

Haji tidak semata-mata dipahami sebagai perintah agama Islam. Ia juga berkaitan erat dengan kebudayaan dan status sosial seseorang. Dalam hal ini, ketika orang sudah menyandang gelar haji, kedudukan sosial seseorang di masyarakat otomatis sudah berbeda dengan mereka yang belum "naik haji". Ia kemudian menjadi "the other" di tengah lingkungan sosialnya, dan kerap kali memperoleh segala bentuk keistimewaan (privilese). Karena itu, haji tidak mesti dilihat dari perspektif agama semata untuk melaksanakan Rukun Islam. Akan tetapi, haji juga bisa diamati dari perspektif lain, karena ia termasuk bagian dari kebudayaan. Dalam sebuah tulisannya, "Haji Bontonompo Kabupaten Gowa: Tinjauan Ekonomi Sosial", Kadir Ahmad, menegaskan hal tersebut:

“...Meskipun haji adalah bagian dari ajaran yang oleh orang Islam dipahami sebagai bagian dari perintah Allah, bukan dari manusia, namun ketika ajaran itu sudah bersentuhan dengan manusia, maka pada waktu yang sama ia lalu menjadi bagian dari kebudayaan." (Ahmad, 2013: 176).

Dengan melihat keragaman kebudayaan di Indonesia, perbincangan haji tentu akan menarik bila dilihat dalam perspektif diversitas budaya. Pada budaya Betawi, misalnya, gelar haji bisa dijadikan modal sosial bagi laki-laki untuk memiliki lebih dari satu istri. Sementara pihak perempuan pada masyarakat Betawi akan merasakan suatu kebanggaan apabila diperistri oleh haji, terlepas apakah ia nantinya menjadi istri pertama atau kedua (Farida, 1999: 38). Di kalangan Masyarakat Petani Santri Gondanglegi, Kabupaten Malang, seperti diulas Zainuddin, ibadah haji merupakan ibadah istimewa dan punya daya tarik luar biasa bagi yang melaksanakan. Dalam kaitan ini, ibadah haji lantas dikaitkan dengan ekonomi, bahwa "haji membuat orang menjadi kaya dan harta yang digunakan untuk berhaji tidak akan pernah habis" (Zainuddin, 2002: 63-83). Ini menunjukkan, dengan pergi haji, harta yang dikumpulkan tidak berkurang, dan sebaliknya, akan terus menjadi semakin banyak.

Gelar haji bagi orang Gorontalo menjadi penanda puncak sosio-religius seseorang. Haji adalah gelar tertinggi umat Islam, dan tidak bisa disamakan dengan gelar formalistis yang diperoleh di bangku sekolah. Haji adalah panggilan Allah, dan orang-orang yang memenuhi panggilan Allah saja, yang akan berkunjung melaksanakan Rukun Islam kelima itu. Oleh sebab itu, berkaitan status sosial dan religiositas, sehingga ada semacam ritual yang kerap dilakukan orang Gorontalo sebelum berangkat haji. Ritual tersebut dinamakan "ritual pembersihan diri", yaitu semacam refleksi diri untuk membersihkan pikiran dan tindakan sosial. Ada ungkapan dalam masyarakat Gorontalo yang terkenal, yaitu "Berhaji di sini dulu (Gorontalo). Masa' mau kotor-kotor pergi ke Tanah Suci", yang dimaknai sebagai bentuk pendekatan kepada Allah, karena mereka akan menuju ke tempat suci. Misalkan, mereka yang dulunya malas bersedekah, kebiasaan itu harus diubah menjadi rajin bersedekah, mereka yang tadinya jarang ke masjid, menjadi mulai rajin berjamaah di masjid, mereka yang dulunya selalu merasa hebat atau angkuh, mulai menghilangkan sifat merasa hebat atau angkuh dari orang lain (Wawancara, Qadhi Wilayah Provinsi Gorontalo, KH. Abdurrasyid Kamaru, 20 Agustus 2017, di Gorontalo).

Meski sering kali mendapat keistimewaan di lingkungan sosial, status haji menjadi beban juga bagi orang yang menyandangnya. Setelah bergelar haji, simbol haji kemudian dijadikan pengontrol atas segala tindakan yang mereka perbuat di dalam kehidupan sehari-hari. Meminjam istilah Michel Foucault, simbol haji lalu menjadi semacam "menara pengawas" (panopticon), sehingga tubuh-tubuh merasa patuh, diawasi, dikontrol, dan didisiplinkan di ruang publik. Efek utama dari panopticon adalah kuasa berfungsi secara 
otomatis. Dalam mekanisme panopticon, individu-individu (haji) menjadi sadar dirinya terus-menerus diawasi oleh masyarakat, dan akhirnya menjadi beban buat individu (Hardiyanta, 1997: 111-16). Pengawasan tersebut akan menyebabkan para haji dan Hajjah akan menjaga setiap perkataan dan tindakan mereka, serta tidak melakukan tindakan yang menyalahi ajaran Islam.

Bentuk pengawasan masyarakat terhadap haji ini, tidak dimaksudkan untuk menyembunyikan akhlak "buruk" haji. Akan tetapi, pengawasan ini dijadikan semacam peringatan, bahwa apabila sudah berhaji dan perilaku serta tindakan tidak berubah, kehajian orang itu bisa dipertanyakan. Apakah mereka pergi haji, karena betul-betul berniat karena Allah Swt., atau semata-mata hanya punya uang (orang kaya). Pada akhirnya, mereka juga akan menyadari, gelar haji tersebut tidak untuk dipertanggungjawabkan kepada masyarakat (profan), melainkan akan dipertanggungjawabkan sendiri-sendiri di akhirat kelak (sakral).

Sosiolog Perancis, Emile Durkheim, mengemukakan, "Yang Sakral" adalah hal-hal yang dilindungi dan diisolasi oleh laranganlarangan (tabu), sedangkan "Yang Profan" merupakan tempat larangan-larangan tersebut diterapkan dan harus tetap dibiarkan berjarak dari hal-hal yang sakral (Durkheim, 1992: 72). Hal-hal yang bersifat sakral selalu diartikan sebagai sesuatu yang superior, berkuasa, yang dalam kondisi normal tidak tersentuh dan selalu dihormati. Sementara, hal-hal yang bersifat profan merupakan bagian keseharian dari hidup dan bersifat biasa-biasa saja. Meski begitu, Durkheim mengingatkan, dikotomi sakral dan profan tidak diartikan sebagai konsep pembagian moral; bahwa yang sakral adalah kebaikan sedangkan profan sebagai keburukan. Bagi Durkheim, kebaikan dan keburukan sama-sama ada di dalam sakral maupun profan. Yang sakral tidak dapat berubah menjadi profan, dan begitu pula sebaliknya, yang profan tidak dapat menjadi sakral (Durkheim, 2003: 34-35)

"Yang Sakral" adalah sesuatu yang terlarang dan terpisah, dan sebagai sesuatu yang terlarang dan terpisah, dirasakan lebih tepat untuk tidak menganggap, bahwa sakral identik dengan sesuatu yang suci. Sebab, dalam hal "Yang Profan" pun terdapat sesuatu yang suci dan buruk, namun tidak berubah menjadi "Yang Sakral". Sebaliknya, di dalam "Yang Sakral" juga bisa terdapat keburukan dan kebaikan sekaligus, tetapi tidak berubah menjadi "Yang Profan". Dengan demikian, konsentrasi utama agama terletak pada "Yang Sakral" sedangkan upacara keagamaan dimaksudkan untuk mendekati "Yang Sakral" (Zainal, 2014: 68).

\section{METODE PENELITIAN}

Jenis penelitian ini adalah kualitatif. Pengumpulan data melalui wawancara, observasi, pengumpulan data-data sekunder, dan pengumpulan literatur berkaitan tema penelitian. Pemilihan informan dilakukan secara sengaja (purposive), yaitu informan yang memahami tema penelitian, mudah diajak bicara, mengerti tentang informasi yang dibutuhkan, dan senang diajak bekerja sama (Endraswara 2006, 121).

Informan dalam penelitian ini adalah Kasi Pembinaan Haji dan Umrah Kanwil Kemenag Provinsi Gorontalo, Kasi Penyelenggara Haji dan Umrah Kemenag Kota Gorontalo, Kepala Kantor Urusan Agama Kemenag Kota Gorontalo, Qadhi Provinsi dan Kota Gorontalo, Imam Masjid Raya Kota Gorontalo, calon jamaah haji, serta beberapa orang Gorontalo yang pernah melaksanakan ibadah haji.

Observasi dilakukan dengan melihat praktik ritual yang dilakukan oleh calon jamaah haji Gorontalo sebelum berangkat ke Tanah Suci dan ritual keluarga pada saat menunggu kepulangan jamaah haji. Sebelum melakukan observasi, peneliti terlebih dulu bertemu dan wawancara, dan selanjutnya membuat janji dengan calon jamaah haji dan keluarga untuk mengikuti ritual yang dia lakukan. Semua calon jamaah haji yang menjadi informan mengizinkan peneliti untuk melihat prosesi ritual "Baca Doa" di rumahnya.

Analisis data dilakukan dengan menelaah data yang tersedia dari berbagai sumber, seperti hasil wawancara, catatan lapangan, dokumen, dan lain-lain. Selanjutnya, mereduksi data, memaparkan data, dan simpulan melalui pelukisan dan verifikasi (Endraswara, 2006: 176). 
Analisis data tidak hanya dijelaskan menggunakan kalimat yang dideskripsikan, tetapi sedapat mungkin memberi penjelasan obyek penelitian (Moleong, 2000: 36).

\section{PEMBAHASAN}

\section{Geografis, Demografis, dan Etnis}

Kota Gorontalo adalah nama Ibukota Provinsi Gorontalo yang berada di Pulau Sulawesi. Provinsi yang merupakan hasil pemekaran dari Provinsi Sulawesi Utara ini, berdiri pada 16 Februari 2001 berdasarkan Undang-Undang Nomor 38 tahun 2000 tentang Pembentukan Provinsi Gorontalo. Situs resmi Provinsi Gorontalo menyebutkan, wilayah Gorontalo terbentuk kurang lebih 400 tahun lalu dan merupakan salah satu kota tua di Sulawesi selain Kota Makassar, Parepare, dan Manado.

Berdasarkan jumlah penduduk pada 2015, Kota Gorontalo dihuni 193.865 jiwa, dan terdiri atas sembilan kecamatan dan 50 kelurahan. Jumlah penduduk dan kecamatan di Kota Gorontalo adalah, Kota Barat (22.995 jiwa), Dungingi (24.808 jiwa), Kota Selatan (22.471 jiwa), Kota Timur (26.731 jiwa), Hulonthalangi (16.123 jiwa), Dumbo Raya (18.263 jiwa), Kota Utara (18.647 jiwa), Kota Tengah (26.063 jiwa), dan Sipatana (17.764 jiwa). Dari sembilan kecamatan, terdapat dua kecamatan yang jumlah penduduknya tergolong banyak, yaitu Kota Timur, 26.731 jiwa, dan Kota Tengah, 26.063 jiwa. Sedang kecamatan yang jumlah penduduknya paling sedikit adalah Hulonthalangi, yaitu 16.123 jiwa (BPS Kota Gorontalo, 2015).

Dari segi etnis, penduduk di Kota Gorontalo tergolong heterogen dan multikultur. Selain penduduk tempatan, Gorontalo juga dihuni migran yang telah ada sejak beberapa abad lalu. Ini pula yang kemudian menyebabkan munculnya kampung-kampung yang didasarkan atas nama etnis mereka. Misalkan, Kampung Bugis-Makassar, Kampung Jawa, Kampung Minahasa, Kampung Bali, Kampung Bajo, dan Kampung Sangihe. Ada juga kampung yang dihuni oleh warga keturunan, seperti Kampung Arab, Kampung Cina, dan Kampung Pakistan (Apriyanto, 2012: 8 dan Hasanuddin dan Amin, 2012: 88-91).
Fenomena pernikahan lintas etnis di kalangan "Orang Selatan" (Bugis dan Makassar) dengan Gorontolo, ternyata membawa dampak positif terhadap kondisi sosial di Gorontalo, terutama menyangkut konflik antar etnis. Hampir tidak pernah ditemukan problem identitas sosial (agama, ekonomi, dan etnis) di Gorontalo. Kondisi ini tentu berbeda dengan kawasan timur lain, seperti Kalimantan Timur, Manado, dan Manokwari, yang terlihat kondusif di permukaan, tetapi sesungguhnya, ibarat bom waktu, ia bisa saja meledak kapan saja, seperti dipaparkan di dalam tulisan Syamsurijal (2016), Syuhudi (2016), dan Saputra (2017).

Selain kawin mawin lintas etnis (Bugis dan Makassar dengan Gorontalo), penyebab tidak terjadinya konflik juga dikarenakan samasama memeluk Islam. Dengan adanya perkawinan tersebut, menyebabkan etnis BugisMakassar dan etnis Gorontalo menjadi sebuah keluarga besar, dan secara sosio kultural berfungsi pula untuk meredam lahirnya konflik. Hasil perkawinan lintas etnis tersebut kemudian melahirkan anak-anak berdarah campuran, sehingga sebagian besar Orang Selatan yang anak-anaknya lahir di era 1980-an ke atas dipastikan memiliki "darah campuran" di dalam tubuhnya (Bugis Gorontalo atau Makassar Gorontalo).

\section{Statistik Agama dan Tempat Ibadat}

Gorontalo identik dengan agama Islam, yakni sebanyak 188.149 orang, atau $97 \%$ penduduk yang mendiami Kota Gorontalo menganut agama Islam. Posisi kedua adalah Kristen, 4.090 jiwa (2,1\%), Buddha, 918 jiwa (0,48\%), Katolik, 630 jiwa (0,33\%), Hindu, 105 jiwa $(0,05 \%)$, dan Konghucu, 5 jiwa $(0,002 \%)$. Sementara rumah ibadat agama Islam berupa masjid dan mushalla, yang paling banyak menghiasi Kota Gorontalo. Masjid berjumlah 299 buah sedangkan mushalla, 28 buah, Gereja Protestan, dua buah, Wihara, Gereja Katolik, dan Klenteng masing-masing satu buah. Hanya rumah ibadat agama Hindu, Pura, yang belum terlihat di kota ini. 


\section{Tradisi Praktik Ritual Berhaji Gorontalo}

Ritual haji masih kental di Kota Gorontalo. Saat musim haji tiba, sebagian besar calon jamaah haji beserta keluarga mengadakan ritual. Mereka percaya, di balik makna ritual haji itu, terkandung banyak kebaikan-kebaikan. Karena itu, ada yang hanya melakukan ritual tersebut di rumah, tetapi ada juga yang melaksanakan ritual beberapa kali. Misalkan, melaksanakan ritual di rumah, tetapi di lain waktu, mereka juga menggelarnya di masjid, majelis taklim, dan organisasi, di mana calon jamaah tersebut aktif sebagai pengurus.

Hingga kini, masih sulit melacak siapa yang pertama kali memperkenalkan ritual haji di Gorontalo. Namun, banyak yang beranggapan, tradisi Islam dan ritual haji itu diperkenalkan oleh para ulama di Gorontalo sekitar tahun 1950an, yang dikenal sebagai Guru Tarekat Naqshabandiyah atau Tarekat Qadiriyah. Mereka, antara lain, KH Abdul Shamad Bula, yang dikenal dengan Tuan Syamadi, KH Abbas Rauf (mantan Qadhi Wilayah Provinsi Gorontalo), KH Adam Zakaria (mantan Qadhi Wilayah Provinsi Gorontalo), KH Naha Akadji di Pohe, dan Kyai Yahya Podungge, seorang sufi yang membaca dan memberi syarah Kitab Futuhat Makkiyah, atau dikenal dengan panggilan Paci Nurjannah (Wawancara, Qadhi Wilayah Provinsi Gorontalo, Abdurrasyid Kamaru, 20 Agustus 2017).

Tulisan Subair, "Ulama Karismatik KH. Hamrain Kau Angurah Atas Ilmu dan Amalnya," (2015: 48-49), menyebutkan, terdapat puluhan ulama Gorontalo yang hidup pada masa perjuangan kemerdekaan Indonesia. Meskipun telah meninggal, mereka masih menancapkan pengaruhnya (ajaran-ajarannya) terhadap kehidupan beragama masyarakat Gorontalo sampai saat ini. Salah satunya, tradisi lokal dan ritual-ritual keagamaan (Subair, 2015: 48-49).

Sebelum berangkat haji, calon haji terlebih dulu telah menyiapkan diri lahir batin, atau ritual "pembersihan diri". Sebelum berangkat haji, pikiran dan perilaku harus dibersihkan dulu. Dalam masyarakat Gorontalo ada ungkapan, "Berhaji di sini dulu (Gorontalo). Masa' mau kotor-kotor pergi ke sana (Tanah Suci)", yang dimaknai sebagai refleksi diri.
Maksudnya, orang yang merencanakan pergi haji sebaiknya lebih banyak mendekatkan diri kepada Allah, karena mereka akan menuju ke tempat yang disucikan Allah. Misalnya, mereka yang dulunya malas bersedekah, kebiasaan itu harus diubah menjadi rajin bersedekah, mereka yang tadinya jarang ke masjid, menjadi mulai rajin berjamaah di masjid, mereka yang dulunya selalu merasa hebat atau angkuh, mulai menghilangkan sifat merasa hebat atau angkuh dari orang lain (Wawancara Qadhi Wilayah Provinsi Gorontalo, KH. Abdurrasyid Kamaru, 20 Agustus 2017, di Gorontalo).

Sebagian besar masyarakat di Gorontalo juga melaksanakan proses ritual haji yang terdiri atas ritual sebelum berangkat haji, ritual saat jamaah di Tanah Suci, dan ritual menunggu kepulangan jamaah haji. Semua ritual haji tersebut dinamakan "Baca Doa", yang di dalamnya berisi Salawati (Selawat Nabi Muhammad SAW), tadarusan (mengaji), dan zikir. Ritual ini dilaksanakan oleh calon jamaah haji dan keluarga jamaah haji yang terdiri atas beberapa tahapan, sebagai berikut:

\section{Ritual Sebelum Berangkat Haji}

Sebelum berangkat haji, calon jamaah haji mengadakan syukuran dengan mengadakan tadarusan (mengaji), zikir, dan Salawati dan barzanji di rumah. Secara umum, ritual ini dimaknai sebagai bentuk syukuran atau tanda syukur seseorang dan keluarga yang akan berangkat ke Tanah Suci. Ritual ini juga dimaksudkan sebagai wujud "pelepasan" calon jamaah haji di lingkungan sosialnya.

Ritual "Baca Doa" ini memanggil seorang ustaz atau imam masjid untuk membaca Salawati. Salawati dibaca sendiri oleh imam atau ustaz, sedangkan undangan yang hadir hanya duduk mendengarkan. Di depan imam ada baki yang di atasnya terdapat gelas berisi air putih, totabu (daun-daun yang sudah ditumbuk menjadi serbuk), polutube (semacam tempat yang di dalamnya diisi arang atau kayu bakar) kue-kue, nasi kuning, dan pisang. Sebelum imam membacakan Salawati, totabu tadi diisi ke dalam polutube yang di dalamnya sudah ada arang atau kayu bakar yang terbakar. Untuk menambah keharuman, totube ini kemudian dicampur gula pasir. 
Setelah imam menyelesaikan Salawati, gelas berisi air putih itu diberikan kepada calon jamaah haji. Air putih itu lalu diminum, dan sisanya disapukan ke muka, rambut, dan bagianbagian tubuh. Bagi orang Gorontalo, meminum dan menyapukan air putih ke bagian tubuh yang telah dibacakan Salawati diyakini untuk mendapatkan berkah air tersebut sebagai obat, supaya jamaah berada dalam kondisi sehat, selamat, dan berkah.

Menurut mereka, air putih itu hanyalah sarana untuk mendekatkan diri, sekaligus meminta perlindungan dan pertolongan kepada Allah Swt. Air putih itu dianggap seperti obat medis yang diberikan dokter. Biasanya, jamaah yang kondisinya sering sakit-sakitan, menggabungkan antara obat dokter (medis) dengan air putih yang telah didoakan. Jamaah haji membawa obat medis dan membawa pula air putih yang telah diisi doa-doa (Wawancara beberapa informan di Gorontalo, Agustus 2017).

Setelah membaca Salawati, biasanya dilanjutkan zikir oleh tamu yang hadir. Namun, tidak semua calon jamaah melakukan zikir dan tadarusan sebelum pemberangkatan. Ritual yang paling umum hanyalah Salawati dan juga barzanji. Sebelum ritual selesai, ustaz atau imam memberikan petuah-petuah dan amalan-amalan yang dilakukan calon jamaah haji dan keluarga yang ditinggalkan. Semua aktivitas "Baca Doa" itu dimaksudkan untuk kemudahan, keselamatan, dan kesehatan calon jamaah haji sejak meninggalkan rumah, hingga pulang ke rumah. Juga, dimaksudkan supaya calon jamaah haji dapat melaksanakan semua Rukun Haji tanpa menemui kendala.

Jadwal pelaksanaan "Baca Doa" tidak menentu. Semua tergantung kesiapan calon jamaah haji. Terkadang dilaksanakan sepekan sebelum masuk asrama haji, dan kadang pula dua atau tiga hari sebelum masuk asrama. Dalam tradisi di Gorontalo, "Baca Doa" tidak hanya sekali dilaksanakan. Ia bisa dilakukan beberapa kali, tergantung jabatan dan aktivitas sosial calon jamaah haji di masyarakat. Karena itu, selain di rumah, "Baca Doa" juga kerap dilakukan di dalam gedung, di masjid, di kantor, dan di organisasi keagamaan.

Ritual "Baca Doa" kerap kali diwarnai tangisan dari orang-orang yang menghadiri acara tersebut. Selain keluarga dekat dan kerabat, calon jamaah haji juga mengundang tetangga, serta kenalan. Setelah "Baca Doa" selesai, calon jamaah haji di akhir acara meminta maaf kepada orang-orang yang hadir. Acara pengucapan maaf inilah yang selalu diwarnai tangisan dari calon jamaah haji dan orang-orang yang hadir. Orangorang yang diundang untuk menghadiri ritual ini selalu menyempatkan diri hadir. Mereka meyakini, ritual tersebut juga merupakan doa kepada mereka untuk diberi kemudahan berangkat haji.

\section{Ritual Keluarga saat Jamaah di Tanah Suci}

Ritual yang umum dilaksanakan keluarga saat jamaah haji berada di Tanah Suci adalah tadarusan (mengaji). Tadarusan dilakukan selama 40 hari berturut-turut sejak calon jamaah haji berangkat hingga sebelum pulang ke tanah air. Meski begitu, ada pula yang melaksanakan tadarusan sebanyak tiga kali dalam sepekan pada hari-hari tertentu, seperti malam Senin, malam Rabu, dan malam Jumat. Mengenai berapa hari melakukan tadarusan sebenarnya tidak terlalu dipersoalkan. Yang penting, sebelum jamaah haji pulang ke tanah air, mereka yang terlibat di acara tadarusan itu sudah menamatkan (khatam) Al-Quran.

Tadarusan dilakukan di rumah jamaah haji dengan memanggil tetangga, pengurus masjid, majelis taklim, dan anak-anak panti asuhan. Dilarang berbicara di sela-sela mengikuti tadarusan. Semua diminta serius mengaji. Setiap orang yang sejak awal mengikuti tadarusan diharuskan mengkhatamkan sebelum jamaah haji tiba di tanah air.

Pada kegiatan tadarusan, keluarga menyiapkan makanan dan minuman, yang dimaksudkan sebagai bentuk penghargaan. Setelah tadarusan, tuan rumah mempersilakan orang-orang (yang melakukan tadarusan) mencicipi makanan dan minuman yang telah disediakan. Setelah hendak pulang, tuan rumah memberikan "sedekah" (amplop yang diisi uang) kepada mereka yang tadarusan.

Jumlah sedekah yang diberikan variatif. Semua tergantung kemampuan tuan rumah. Karena itu, ada yang hanya memanggil empat orang untuk tadarusan di rumah, seperti dilakukan Hajjah Rukmini. Umumnya, mereka 
yang dipanggil tadarusan diberikan sedekah minimal 250 ribu rupiah per orang. Mekanisme pemberian sedekah pun beragam. Ada yang diakumulasikan setelah mengkhatamkan AlQuran 30 juz, dan ada juga yang diberikan langsung setelah menyelesaikan tadarusan satu juz, pada malam itu juga.

Dalam sekali tadarusan diwajibkan membaca satu juz. Tadarusan sering kali dilakukan sehabis isya, sedangkan jadwal tadarusan bisa dilakukan setiap malam Jumat, sepekan tiga kali, dan setiap hari. Inti dari kegiatan tadarusan adalah mengkhatamkan AlQuran sebelum jamaah haji menginjakkan kaki di tanah air. Selain sedekah, mereka yang terlibat di dalam ritual itu sering kali diberikan pula hadiah dari jamaah haji, seperti sajadah, tasbih, dan air zamzam.

Meski begitu, ada juga jamaah yang tidak memberikan sedekah kepada orang yang tadarusan di rumahnya. Tuan rumah hanya menyediakan makanan dan minuman semampunya. Hal ini dialami Hajjah Salmiah (samaran), ketika melaksanakan ibadah haji pada 2014. Kebetulan, mereka yang melakukan tadarusan adalah ibu-ibu Majelis Taklim, di mana Hajjah Salmiah juga terlibat aktif di situ. Sejak jamaah berangkat haji, setiap malam sehabis Isya, anggota Majelis Taklim tadarusan di rumah anggotanya yang lagi melaksanakan ibadah haji.

Apabila anggota jamaah haji berangkat lebih dari satu orang, mereka tinggal membagi jadwal kegiatan tadarusan. Misalkan, sehabis Isya di rumah Ibu A, dan setelah itu, langsung ke rumah Ibu $\mathrm{B}$, pada hari itu juga. Hal ini setiap hari dilakukan hingga menamatkan Al-Quran. Aktivitas dari Ibu-ibu Majelis Taklim yang tidak diberikan sedekah itu, adalah semacam bentuk balas jasa (reprositas). Sehingga, ketika di lain waktu ada lagi ibu-ibu dari Majelis Taklim yang melaksanakan ibadah haji, orang yang sudah haji ini juga ikut melakukan tadarusan, serta menghadiri undangan ritual haji lainnya di rumah calon jamaah haji.

Ada juga keluarga yang membakar kemenyan saat jamaah di Tanah Suci. Jadi, di sela-sela tadarusan, mereka membakar kemenyan, yang diletakkan di dalam kamar calon jamaah haji, dan pada beberapa bagian tertentu di dalam rumah. Secara fungsional spiritual, asap kemenyan diyakini naik ke langit dan ikut bersama amalan-amalan ritual yang mereka laksanakan di rumah. Membakar dupa juga diyakini bisa menghubungkan orang-orang di rumah dengan keluarga mereka yang tengah melaksanakan haji. Jadi, terjadi semacam kontak batin antara keluarga di rumah dengan jamaah di Tanah Suci. Orang Gorontalo juga percaya, bau asap kemenyan itu dapat tercium oleh keluarganya yang lagi berhaji.

Di samping itu, menyertakan dupa pada setiap aktivitas ritual (Salawati dan barzanji), sudah menjadi pemandangan umum hampir semua orang Gorontalo. Menurut Qadhi Wilayah Provinsi Gorontalo, KH. Abdurrasyid Kamaru, dupa digunakan untuk mengharumkan ruangan atau rumah. Dengan mencium sesuatu yang harum, hal itu bisa berdampak kepada ketenangan hati dan pikiran, sehingga jiwa menjadi tenang dan rileks. Hal ini juga merupakan refleksi kita kepada Rasulullah, karena Baginda Rasulullah menyukai yang harum-harum.

Ketua Dewan Adat Provinsi Gorontalo, Karim Jahya Pepeda, mengaku sering mencium bau wangi kemenyan, serta bau makanan yang disediakan di rumah saat dirinya melaksanakan ibadah haji. Ia mengetahui apa yang dilakukan keluarga ketika menghubungi hal tersebut kepada keluarga di rumah di sela-sela waktu berada di "Tanah Suci" (Wawancara, Karim Jahya Pepeda, 23 Agustus 2017, di Gorontalo).

Selama proses menunggu jamaah haji pulang ke rumah, keluarga yang ditinggalkan di rumah tidak diperbolehkan melakukan hal-hal yang bertentangan dengan ajaran agama. Antara lain, berbicara kotor, bergosip, dan mencuri. Bila keluarga melakukan perbuatan yang bertentangan dengan agama, orang Gorontalo meyakini jamaah haji akan mendapat kesulitan di sana. Misalkan, menemui kendala saat melaksanakan rukun-rukun haji, tersesat, atau kehilangan harta benda.

\section{Ritual Penjemputan Jamaah Haji}

Setelah mengetahui kepastian jadwal kepulangan keluarga yang berangkat haji, keluarga di rumah juga menyiapkan penjemputan di bandara. Mereka menjemput 
ramai-ramai menggunakan beberapa mobil. Selain keluarga dan kerabat, ada juga tetangga dekat yang ikut menjemput di bandara. Di samping itu, ada juga keluarga, kerabat, dan tetangga yang hanya menunggu di rumah orang jamaah haji. Sambil menunggu di rumah, mereka ada yang tadarusan (apabila belum sempat khatam Al-Quran).

Bila sudah khatam Al-Quran, biasanya dilakukan Salawati, yang dipimpin seorang ustaz/imam masjid, yang sengaja diundang tuan rumah. Salawati ini dimaknai sebagai bentuk rasa syukur keluarga atas kesehatan dan keselamatan jamaah haji hingga pulang ke rumah. Setelah jamaah haji tiba di rumah, seorang ustaz lalu memimpin doa yang isinya berupa harapan semoga hajinya menjadi Haji Mabrur.

Ritual haji di Gorontalo adalah upaya calon jamaah untuk menghilangkan perasaan cemas, seperti dikatakan George Homans. Pengalaman spiritual, kendala yang ditemui di Tanah Suci, seperti tiba-tiba menderita sakit, kehilangan dompet, dan sebagainya, yang diceritakan oleh orang-orang yang sudah pernah berangkat haji, menjadikan ritual haji ini sebagai persyaratan utama bagi calon jamaah haji. Pelaksanaan ritual haji juga menandakan, calon jamaah haji merasakan apa yang dikatakan Turner sebagai "kelahiran kembali" untuk menuju sebuah "kehidupan baru".

\section{Hubungan Haji Dikaitkan dengan Konteks Sosial}

Status sosial seseorang otomatis ikut terdongkrak naik ketika menyandang gelar haji. Panggilan "Pak Haji" atau "Bu Hajjah" menjadikan mereka pembeda (distinction), meminjam istilah Pierre Bourdieu, dengan orang lain, terutama yang belum berhaji. Secara singkat, distinction diartikan tindakan membedakan diri seseorang terhadap orang lain untuk menunjukkan status sosialnya di masyarakat. Pembeda biasanya dilakukan oleh kelas menengah ke atas untuk memperlihatkan kepada masyarakat atas statusnya yang khas dibandingkan dengan kelas ekonomi yang lebih rendah (Wattimena 2012, 4). Dengan adanya pembeda tersebut, masyarakat dengan sendirinya akan mengetahui, bahwa status sosial ekonomi seseorang yang telah bergelar haji lebih tinggi dibandingkan orang yang belum berhaji.

Laki-laki dan perempuan haji di Gorontalo, misalnya, sering memakai songkok putih khas haji, atau memakai penutup rambut perempuan khas haji di ruang publik. Secara tidak langsung, hal ini juga menunjukkan mereka berbeda kelas dengan orang lain (yang belum berhaji). Dengan demikian, gelar haji merupakan salah satu upaya untuk mengangkat strata sosial mereka dan keluarga di masyarakat. Mereka yang dulunya dipandang sebagai "orang biasa", tetapi setelah bergelar haji, memperoleh kedudukan sosial yang istimewa. Pada kegiatan upacara sosial (pernikahan) dan upacara siklus hidup (life cycle), orang yang bergelar haji sering kali mendapatkan posisi privelege (keistimewaan). Misalkan, disediakan tempat duduk di deretan terdepan bersamaan duduknya para tokoh yang dianggap terpandang.

Gelar haji dapat pula mengubah mindset masyarakat terhadap perilaku seseorang yang menyandang haji. Orang yang bergelar haji dianggap orang alim dan religius. Ada anggapan, tokoh agama, tokoh masyarakat, dan pejabat di instansi pemerintahan merasakan ada sesuatu yang belum lengkap pada dirinya bila belum berhaji.

Dalam memandang gelar haji, orang Gorontalo tidak menilai dari tingkat pendidikan yang bersangkutan. Artinya, sepanjang orang itu bergelar haji, masyarakat spontanitas memberikan kesan positif kepada mereka. Beberapa identitas sosial baru pun secara otomatis melekat pada diri seorang haji. Selain disegani, dihormati, dan diberikan kedudukan penting pada upacara-upacara sosial, juga mereka dianggap lebih memahami agama Islam. Karena itu, ketokohan seseorang di tengah masyarakat terkesan belum lengkap apabila belum bergelar haji.

Dalam konteks Gorontalo, kedudukan tokoh agama dianggap lebih spesial dibanding posisi lain. Sebab, dalam diri seseorang terkadang melekat beberapa status, misalkan tokoh masyarakat, tokoh agama, dan pejabat. Orang yang bekerja di instansi kementerian agama, misalnya, terkadang dilabeli oleh masyarakat dengan tiga status sosial tersebut (tokoh masyarakat, tokoh agama, dan pejabat). 
Bagi orang Gorontalo, naik haji adalah peristiwa yang sangat disakralkan, dan diibaratkan menuju kematian. Tak ada yang bisa memberi garansi, bahwa mereka akan balik lagi bertemu keluarganya. Boleh jadi, setibanya di sana mereka menderita sakit, atau bahkan meninggal. Karena itu, sebelum berangkat haji, mereka (calon haji) telah menyiapkan segala sesuatunya untuk keluarga yang mereka tinggalkan di rumah.

Haji dikaitkan dengan status seseorang di dunia dan akhirat, dan juga menjadi penanda puncak status sosio - religius seseorang. Orang Gorontalo berpandangan, haji adalah gelar tertinggi umat Islam. Ia berbeda, dan tidak bisa disamakan dengan gelar formalistis yang diperoleh di bangku sekolah. Haji adalah panggilan Allah, dan orang-orang yang memenuhi panggilan Allah saja, yang akan berkunjung melaksanakan Rukun Islam kelima itu. Apabila setelah berhaji dan perilakunya berubah, terutama terlihat lebih agamis, masyarakat beranggapan orang itu betul-betul layak menyandang gelar haji. Sebaliknya, apabila perilaku seorang haji itu di dalam kehidupan sehari-hari terlihat tidak mengalami banyak perubahan, dan justru tetap melakukan perbuatan yang dilarang agama, masyarakat menganggap orang tersebut belum berhak bergelar haji.

Dalam konteks Gorontalo, secara sosial religius, seseorang itu dianggap layak menyandang gelar haji dipandang dari tindakan dan perilaku mereka. Tanpa disadari oleh seorang haji, masyarakat yang terkadang memberi penilaian terhadap gelar haji seseorang, dengan membandingkan perilaku orang bersangkutan sebelum dan setelah berhaji. Dengan kondisi seperti itu, masyarakatlah yang mendefinisikan apakah orang itu benar-benar telah berhaji atau tidak, dengan mengamati perilakunya (akhlaknya).

Dari sini dapat dilihat, mereka yang bergelar haji memiliki beban berat di masyarakat, karena segala perilaku mereka akan terus diawasi oleh masyarakat. Gelar haji akan menjadi pengontrol atas apa yang mereka lakukan di ruang publik dan domestik. Gelar haji juga akan mendisiplinkan tubuh, baik perilaku, tindakan, maupun cara berpakaian. Dengan gelar haji, mereka merasa diawasi oleh masyarakat, sehingga merasa khawatir melakukan hal-hal yang bisa mendatangkan stigma. Misalkan, haji laki-laki tidak boleh bercelana pendek dan tidak boleh memakai kaos oblong di ruang publik, serta menjaga lidah di dalam berkata-kata (tidak menyakiti perasaan orang) (Wawancara Noho Adam, Imam di Kelurahan Tanjung Keramat, Kecamatan Hulonthalangi, Gorontalo, 18 Agustus 2017).

Seorang informan, Nur Fajri, menceritakan, tetangganya yang telah berhaji hingga kini masih menjadi bahan pembicaraan, karena perilakunya dianggap tidak berubah. Selama ini, tetangganya yang berprofesi pedagang, dikenal temperamental, karena sering kali "bicara kasar", dan marah-marah. Setelah pergi haji, para tetangga berharap perilaku temperamentalnya akan hilang, atau minimal berkurang, dan lebih sabar melayani pembeli di warungnya. Namun, apa yang terjadi? Setelah bergelar haji, perilaku laki-laki itu, ternyata tidak berubah, dan akhirnya jadi perbincangan negatif masyarakat sekitar.

Nur Fajri menyatakan, perilaku seseorang semestinya berubah menjadi lebih baik setelah berhaji menurut persepsi masyarakat sekitar. Apalagi, sebelum berangkat haji, calon haji melaksanakan serangkaian ritual, termasuk "pembersihan diri". Karena beratnya gelar haji tersebut bagi orang Gorontalo, sehingga mereka akan berpikiran matang untuk berangkat haji. Artinya, meski dari segi finansial dan fisik misalkan mereka sanggup, namun mereka juga harus menyiapkan diri secara mental. Mereka tidak ingin gelar haji yang disandangnya itu, justru menyebabkan dirinya diberikan stigma oleh lingkungan sekitarnya.

Kasim Yasin, Imam Masjid Baiturrahim Kota Gorontalo, mengaku gelar haji memang sungguh berat. Tetapi, kata dia, seperti itulah makna haji sesungguhnya. Gelar haji akan membatasi gerak-gerik seseorang dan menjadi alarm (pengingat) akan sebuah perbuatan yang bisa mendatangkan dosa. Apabila sudah berhaji dan perilaku serta tindakannya tidak berubah, kehajian orang itu bisa dipertanyakan. Apakah mereka pergi haji, karena betul-betul berniat karena Allah Swt., atau semata-mata hanya punya uang (orang kaya). 


\section{PENUTUP}

Berdasarkan temuan dan analisis data dapat disimpulkan, bahwa sebagian besar masyarakat Islam di Gorontalo masih memandang penting ritual pelaksanaan haji. Karena itu, sebelum berangkat haji, calon jamaah haji di Gorontalo melaksanakan serangkaian ritual haji yang dikenal dengan "Baca Doa", yang berisi Salawati, barzanji, tadarusan, dan zikir. Secara umum, serangkaian ritual tersebut juga merupakan refleksi seseorang yang akan berangkat haji, yang diharapkan ada perubahan perilaku ke arah yang lebih baik dari sebelumnya (ketika belum bergelar haji).

Ritual "Baca Doa" yang terdiri atas ritual sebelum berangkat ke Tanah Suci, ritual keluarga saat menunggu jamaah haji, dan ritual penjemputan jamaah haji, dimaknai sebagai bentuk syukur calon jamaah haji, karena bisa berangkat haji, sekaligus pamit kepada lingkungan sosialnya. Dalam serangkaian ritual tersebut, terselip pula harapan semoga Allah Swt. memberikan kesehatan, kemudahan, keselamatan kepada calon jamaah haji selama melaksanakan ibadah haji, serta menjadi Haji Mabrur.

Ritual lain yang dilakukan calon jamaah haji adalah "pembersihan diri", di mana calon jamaah haji terlebih dulu "berhaji" di Gorontalo sebagai bentuk refleksi diri sebelum berangkat haji. Pada ritual ini, calon jamaah haji diminta untuk lebih mendekatkan diri lagi kepada Allah Swt., dan mengubah perilaku yang sebelumnya dianggap buruk menjadi lebih baik. Karena itu, sepulang dari haji, mereka "dituntut" untuk tetap berperilaku baik di masyarakat. Segala macam ritual yang dilaksanakan oleh calon jamaah haji adalah sebagai bentuk untuk menghilangkan perasaan cemas sebelum berangkat haji dan ketika berada di Tanah Suci Mekkah, serta mengalami "kelahiran kembali".

Gelar haji pada masyarakat Gorontalo ikut pula menaikkan status sosial-religius di seseorang di lingkungan sosialnya. Hal ini dapat dilihat pada aktivitas life cycle (siklus hidup) dan upacara keagamaan (tahlilan), di mana haji diberi tempat duduk sejajar dengan pejabat, tokoh agama, dan tokoh masyarakat. Orang yang bergelar haji juga dianggap alim dan religius. Bahkan, ada anggapan, tokoh agama, tokoh masyarakat, dan pejabat di instansi pemerintahan merasakan ada sesuatu yang belum lengkap pada dirinya bila mereka belum berhaji.

\section{UCAPAN TERIMA KASIH}

Penulis mengucapkan terima kasih kepada Kepala Balai Litbang Agama Makassar yang memercayakan peneliti untuk melakukan penelitian ini. Penulis juga menyampaikan terima kasih kepada Qadhi Wilayah Provinsi Gorontalo, KH, Abdurrasyud Kamaru, Ketua Dewan Adat Provinsi Gorontalo, H. Karim Jahya Papeda, Kepala Urusan Agama Kementerian Agama Kecamatan Hulontalangi, H. Fikri Hioda, serta informan lain yang tidak bisa disebutkan satu per satu, yang banyak memberikan bantuan saat penelitian berlangsung. Penulis juga mengucapkan terima kasih kepada jajaran redaksi Jurnal Al-Qalam, karena memuat tulisan ini.

\section{DAFTAR PUSTAKA}

Ahmad, Kadir. 2013. "Haji Bontonompo Kabupaten Gowa: Tinjauan Ekonomi Sosial." Al-Qalam 19 (2).

Al-Kumayi, Sulaiman. 2011. Islam Bubuhan Kumai. Perspektif Varian Awam, Nahu, dan Hakekat. Jakarta: Kementerian Agama RI Badan Litbang dan Diklat Puslitbang Kehidupan.

Apriyanto, Joni. 2012. Sejarah Gorontalo Modern, dari Hegemoni Kolonial ke Provinsi. Yogyakarta: Penerbit Ombak.

BPS Kota Gorontalo. 2015. Kota Gorontalo dalam Angka 2015. Gorontalo: BPS Kota Gorontalo.

Bustanuddin, Agus. 2007. Agama dalam Kehidupan Manusia. Jakarta: Raja Grafindo.

Djamari. 1993. Agama Dalam Perspektif Sosiologi. Bandung: Alfabeta.

Durkheim, Emile. 1992. Sejarah Agama; The Elementary Forms of The Religious Life. New York: New York: Free Press.

_. 2003. Sejarah Agama. Edited by Inyiak Ridhwan Muzir. Yogyakarta: Ircisod.

Endraswara, Suwardi. 2006. Metode Penelitian Kebudayaan. Yogyakarta: Gadjah Mada University Press. 
Farida, Anik. 1999. "Haji dalam Stratifikasi Sosial Masyarakat Betawi Pedagang di Kelurahan Jombang, Jakarta Selatan." Penamas 33 (XII).

Hamid, Abu. 1982. "Selayang Pandang Uraian Tentang Islam dan Kebudayaan Orang Bugis-Makassar." In Bugis-Makassar dalam Peta Islamisasi Indonesia, edited by Andi Rasdiyanah. Ujung Pandang: IAIN Alauddin.

Hardiyanta, Petrus Sunu. 1997. Disiplin Tubuh Bengkel Individu Modern. Yogyakarta: LKiS.

Hasanuddin dan Amin, Basri. 2012. Gorontalo dalam Dinamika Sejarah Masa Kolonial. Yogyakarta: Ombak.

Idris, Syarifuddin. 2017. "Konstruksi Ritual Ibadah pada Masyarakat Sekitar Gunung Bawakaraeng Kab. Gowa.” Al-Qalam 23 (2).

Koentjaraningrat. 1985. Beberapa Pokok Antropologi Sosial. Jakarta: Dian Rakyat.

Maarif, Zainul. 2017. "Kapitalisasi Haji dan Umroh." Syiarnusantara.Id. 2017.

Madani, Malik. 1984. "Citra Status Sosial Para Haji di Kalangan Masyarakat Pedesaan Madura." Jurnal Al Jamiah 8.

Moleong J, Lexi. 2000. Metode Penelitian Kualitatif. Bandung: Rosda Karya.

Saputra, Ali. 2017. "Laporan Penelitian Menguatnya Politik Identitas dan Problem Kerukunan Beragama di Manokwari." Makassar.
Subair. 2015. "Ulama Kharismatik KH. Hamrain Kau Anugrah Atas Ilmu dan Amalnya." AlQalam 21 (1).

Suprayogo, Imam. 2001. Metode Penelitian Sosial Agama. Bandung: Remaja Rosda Karya.

Syamsurijal. 2016. "Laporan Penelitian Bangkitnya Suara-Suara Yang di Bungkam; Politik Identitas dan Babak Baru Toleransi Beragama di Kaltim." Makassar.

Syuhudi, Muhammad Irfan. 2016. "Geliat Politik Identitas di Kota Manado." Harmoni 15 (2): 56-66.

Wattimena, Reza A.A. 2012. "Berpikir Kritis Bersama Pierre Bourdieu Filsuf dan Sosiolog Asal Prancis.” Rumah Filsafat. 2012.https://rumahfilsafat.com/2012/04/1 4/ sosiologi-kritis-dan-sosiologi-reflektifpemikiran-pierre-bourdieu/

Winangun, Y.W. Wartajaya. 1990. Masyarakat Bebas Struktur, Liminitas dan Komunitas Menurut Victor Turner. Yogyakarta: Kanisius.

Zainal, Asliah. 2014. "Sakral Dan Profan Dalam Ritual Life Cycle: Memperbincangkan Fungsionalisme Emile Durkheim." $A l$ Izzah 9 (1): 61-71.

Zainuddin, M. 2002. "Laporan Penelitian Fenomena Haji di Kalangan Petani Santri di Gondanglegi." Malang. 
14 | Jurnal “Al-Qalam” Volume 25 Nomor 1 Juni 2019 